\title{
THE LITUUS AND AUGUSTAN PROVINCIAL COINAGE ${ }^{1}$
}

\begin{abstract}
Summary: This paper examines the importance of the lituus on Augustan provincial coinage. On local coins of some thirty cities in Africa and Asia, Augustus' obverse portraits are accompanied by a lituus, the symbol of the augurs. One of Augustus' most important priestly offices was that of an augur. Romulus' most famous achievement as an augur was the foundation of Rome. When Augustus became an augur in $43 \mathrm{BC}$, it was particularly Romulus' role as a founder that Augustus emulated the most. Augustus considered himself to be the second founder of Rome, and also founded, re-founded, and reorganized numerous cities in the Roman provinces. I argue, then, that given the far-reaching evidence of the lituus on Augustan provincial coinage, the prominence of Augustus' position as an augur is not only evident through his provincial (re)foundations, but also through his visual imagery.
\end{abstract}

Key words: Africa, Asia, augur, Augustus, conditor, coins, (re)founder, (re)foundation, lituus, Roman provinces, Rome, Romulus

${ }^{1}$ I would like to thank the organizers (Patricia Johnston, Attilio Mastrocinque, and Sophia Papaioannou) of the Symposium Veronese on the Age of Augustus held on June 18-20, 2014 for the opportunity to participate and to thank all those who were present for their helpful comments. I would also like to thank László Takács for the publication of this conference proceedings. Finally, I would like to extend gratitude to Dominic Rathbone for his constant encouragement and guidance.

In my paper, I use the following Numismatic Catalogues and Abbreviations: Sutherland, C. H. V. - KRAAY, C.: Catalogue of Coins of the Roman Empire in the Ashmolean Museum. Part I: Augustus (c. 31 BC-AD 14). Oxford 1975 [AMCRE I]; MATTINGLY, H.: Coins of the Roman Empire in the British Museum. Vol. I: From Augustus to Vitellius. London 1923 [BMCRE I]; GRUEBER, H. A.: Coins of the Roman Republic in the British Museum. London 1910 [BMCRR I-III]; GIARD, J. B.: Bibliothèque Nationale: Catalogue des monnaies de l'empire romain. I: Auguste. Paris 1976 [CBN I]; BANTI, A. - SIMONETTI, L.: Corpus Nummorum Romanorum. Rome 1972 [CNR]; MATTINGLY, H. - SydENHAM, E. A.: Roman Imperial Coinage. Vol. I: Augustus to Vitellius. London 1923 [RIC I]; SUTHERLAND, C. H. V.: Roman Imperial Coinage. Vol. I: From 31 BC to AD 69. London 1984 [RIC I']; BURNETT, A. - AMANDRY, M. - RiPOllÈs, P.: Roman Provincial Coinage. Vol. I: From the death of Caesar to the death of Vitellius (44 BC-AD 69). London 1992 [RPC I]; CRAWFORD, M.: Roman Republican Coinage. Cambridge 1974 [RRC]. 


\section{INTRODUCTION}

One of Augustus' most significant priestly offices was that of an augur. It was a coveted office held by Romulus, and Romulus' best known achievement as an augur was the founding of Rome. When Augustus became an augur, it was specifically Romulus' role as a founder that he associated himself with the most. The lituus is the most common priestly emblem to be found on Augustan mainstream and provincial coins. It is the symbol of the augurs, the Roman priesthood in charge of auguria and auspicia, and is a curved staff. ${ }^{2}$ In particular, on local coins of some thirty cities in Africa and Asia, Augustus' obverse portraits are accompanied by a lituus. This is an interesting phenomenon because the simpulum (sacrificial ladle), the symbol of the pontifices, only appears rarely although Augustus was a pontifex since $48 \mathrm{BC}$ and became Pontifex Maximus in 12 BC. As he points out in Res Gestae 7. 3, Augustus was in fact a member of all the priestly colleges.

This reflects a general pattern of representation of the lituus on Republican coins as well as in Augustan art. The reason for Augustus' predominant use of the lituus in visual imagery lies in the augur's many duties; but, above all, the augur's role as a founder. Augustus emulated Romulus in a myriad of ways; but he particularly linked himself with Romulus' role as the first founder of Rome. It is traditionally said that Romulus, as the optimus augur, founded the city of Rome by means of augury. Augustus is considered to be the second founder of Rome and also founded, re-founded, or reorganized numerous cities in the Roman provinces.

\section{THE LITUUS ON AUGUSTAN MAINSTREAM COINAGE}

The lituus is the most common priestly emblem found on Augustan mainstream coins. As early as $42 \mathrm{BC}$ one of the reverse types depicting Octavian as an equestrian statue (Fig. 2) 3 shows him holding a lituus in his right hand, perhaps commemorating that he became an augur in late $43 \mathrm{BC}$. The lituus then accompanies coin portraits of Octavian/Augustus. In $41 \mathrm{BC}$, the head of Octavian appears with a lituus on the reverse of a coin (Fig. 3$)^{4}$ minted by Antony with Antony's head and a capis (jug) on the obverse. Octavian minted a reverse type in $36 \mathrm{BC}$ depicting a prospective image of the temple of Divus Julius (Fig. 4$)^{5}$ as this temple was only dedicated in 29 BC. The cult statue of Divus Julius shown here is seen veiled and togate (wearing a toga), holding a lituus in his right hand. ${ }^{6}$ The AEGVPTO reverse type depicting a crocodile (Fig. 5) minted at Rome in $28 \mathrm{BC}$, has an obverse type depicting the head of Octavian with a lituus. At Pergamum, cistophori dated to c. 27-26 BC depict an obverse portrait

\footnotetext{
${ }^{2}$ Fig. 1. Imperial date, Nemzeti Múzeum, Budapest.

${ }^{3}$ Fig. 2. RRC 497/1.

${ }^{4}$ Fig. 3. RRC 517/7.

${ }^{5}$ Fig. 4. RRC 540/1.

${ }^{6}$ On Julius Caesar as an alter Romulus (particularly in the role of a founder), see pp. 56-57 and 59.

${ }^{7}$ Fig. 5. RRC 275a-b.
} 
of Augustus with a lituus for three reverse types all with the legend AVGVSTVS and showing either a Capricorn bearing a cornucopia within a laurel wreath (Fig. 6) ${ }^{8}$ a Sphinx, or six bunched corn-ears. ${ }^{9}$ In 13 BC, the Roman minter C. Marius Tro issued eight coin types with obverse portraits of Augustus depicting the lituus. Amongst them are the reverse types portraying Augustus and Agrippa togate and standing, each holding a roll with a capsa at their feet, Augustus veiled and togate holding a simpulum, the head of Julia between the heads of Augustus and Agrippa with a corona civica (a crown made of oak leaves) above, and Augustus veiled and togate ploughing oxen before city walls. ${ }^{10}$

\section{THE LITUUS ON AUGUSTAN PROVINCIAL COINAGE}

The lituus is also by far the most common priestly emblem on Augustan provincial coins. It is almost always found on the obverse and accompanies the portrait head of Augustus. It is only found in the provinces of Africa and Asia and on just one obverse type from Caesaraugusta in Spain.

In Africa, for instance, the lituus is found on obverse portraits of Augustus from Colonia Iulia Pia Paterna (in Tunisia). An obverse portrait of Augustus with a lituus was issued at Leptis Minor (in Tunisia) around $20 \mathrm{BC}$ and another from Hadrumetum (in Tunisia) was issued in 8-7 BC by the proconsul P. Quinctilius Varus. L. Passienus Rufus, proconsul of Thaena, minted two obverse types with an Augustan portrait showing a lituus in AD 3 and AD 10-14. Incidentally, the type issued in AD 10-14 has a reverse portrait of Tiberius with a lituus as well. At Sabratha (in Libya), the lituus is seen on the reverse portrait of Augustus and at Oea (in north Africa) on the obverse. $^{11}$

In the province of Asia, the lituus is found on a multitude of obverse portrait issues. A majority of these coins were minted in cities throughout the region of Phrygia (the western part of Asia). For instance, Augustus is seen with the lituus at Eumenea, Acmonea, Amorium, and Prymnessus. At Laodicea, an obverse Augustan portrait with a lituus was issued in $15 \mathrm{BC}$. At Tralles, an obverse portrait of Augustus dated to around $2 \mathrm{BC}$ is accompanied with the lituus. ${ }^{12}$

${ }^{8}$ Fig. 6. $R I C \mathrm{I}^{2} 489$.

${ }^{9}$ RIC $1^{2} 487$ and 490 .

${ }^{10}$ Figs 7-10, respectively. RIC I $\mathrm{I}^{2} 397,398,404,402,399,403,406$, and 408.

${ }^{11}$ Figs 11-14 for Colonia Iulia Pia Paterna, Thaena, Sabratha, and Oea, respectively. RPC I 760, 809,814 , and 828. For a full list of the lituus on Augustan coin portraits in the province of Africa, see $R P C$ I: Paterna 758, Oea 826, Hadrumetum 775, Leptis Minor 784 and 786, Cercina 802, Thaena 803 and 808, and Sabratha 812-813 and 815.

${ }^{12}$ Figs 15-20 for Eumenea, Acmonea, Amorium, Prymnessus, Tralles, and Laodicea, respectively. $R P C$ I $3142,3167,3231,3196,2647$, and 2895. For a full list of the lituus on Augustan coin portraits in the province of Asia, see RPC I: Acmonea 3164-3165, 3168, Amorium 3232-3234, Methymna 2337, Dioshieron 2556, Apollonia Salbace 2863, Apamea 3128, Sebaste 3154, Siblia 3161, Prymnessus 3198, Midaeum 3229, Erythrae 2505, Trapezopolis 2847, Laodicea 2894, Synnada 3178, Lampsacus 2276, and Eucarpia 3159. 


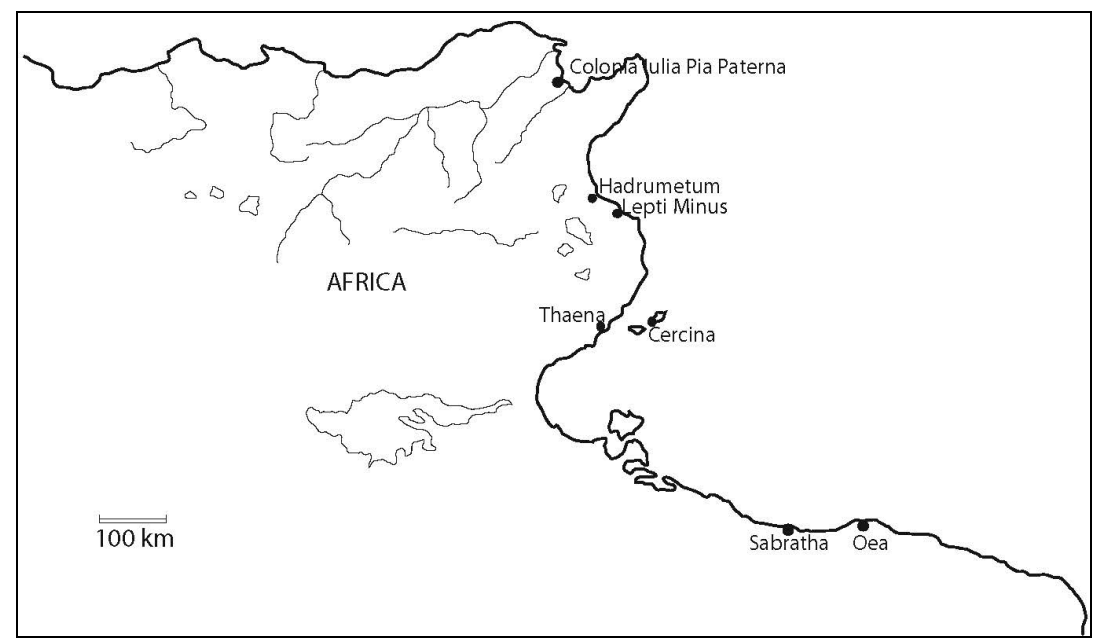

Map 1: Lituus on Augustan obverse coin portraits in Africa

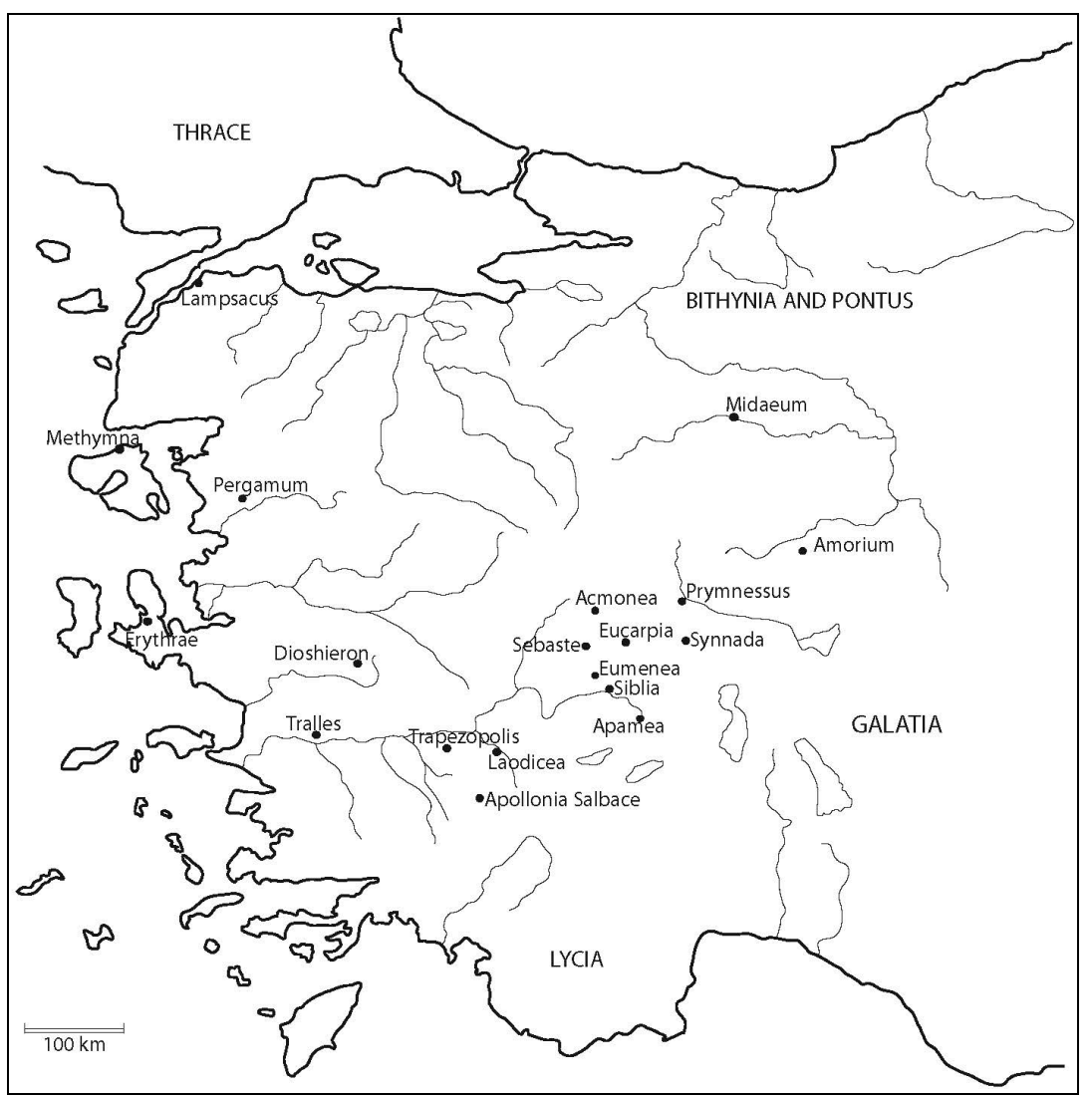

Map 2: Lituus on Augustan obverse coin portraits in Asia 


\section{OTHER PRIESTLY EMBLEMS}

On mainstream coinage, other than the lituus accompanying obverse portraits of Augustus, the simpulum is depicted together with the lituus, as already seen on Figure 10. Two coins, minted by the same gens in Rome, in 16 BC by C. Antistius Vetus (Fig. 21$)^{13}$ and in $13 \mathrm{BC}$ by C. Antistius Reginus, show a reverse type with the priestly symbols of the four major priesthoods to which Augustus belonged (lituus for the auguratus, simpulum for the pontificatus, tripod (sacrificial stand) for the quindecimviri and a patera (libation bowl) for the septemviri epulonum) ${ }^{14}$ On quadrantes from $9 \mathrm{BC}$ minted in Rome, the lituus is seen with the simpulum (Fig. 22). ${ }^{15}$ On the Principes Iuventutis type, minted in Lugdunum from 2 BC to AD 9, Gaius and Lucius Caesar are depicted with symbols of their respective priesthoods, a simpulum for Gaius as pontifex and a lituus for Lucius as augur ${ }^{16}$ (Fig. 23). ${ }^{17}$ Other priestly emblems are even rarer on Augustan provincial coins. On obverse portraits, Augustus is seen with the apex (leather-skull cap with a chin strap worn by a flamen) only at Hadrumetum, and then the lituus is combined with the praefericulum (tall vase with a handle used in sacrifices) at Oea and with the simpulum in Caesaraugusta (Fig. 24) ${ }^{18}$ On one obverse type from Caesaraugusta, Fig. $25,{ }^{19}$ Augustus is seen standing on a basis holding a simpulum with Gaius and Lucius beside him. The lituus, simpulum, aspergillum (stick with long horse-hair attached at one end used to sprinkle lustral water), securis (axe), and apex appear ten times on reverses. ${ }^{20}$

\section{THE LITUUS ON REPUBLICAN COINAGE}

Again, the lituus is the most dominant priestly emblem on Republican coins. At first, it was simply a symbol of the augurate used by Roman minters to advertise a family member's office as an augur, as seen, for instance, on a reverse type of C. Minucius Augurinus, minted in Rome in $135 \mathrm{BC}$, depicting a togate figure holding a lituus (Fig. 26) ${ }^{21}$ and on a reverse type of L. Pomponius Molo, minted in Rome in $67 \mathrm{BC}$, that shows Numa, the second king of Rome, standing at an altar holding a lituus (Fig. 27). ${ }^{22}$ Pomponius claimed descent from Numa through his son Pompo, and Numa was certainly an augur, as is seen, for instance, in Livy 1.20.7 where Numa consults Jupiter Elicius by augury - Ad ea elicienda ex mentibus divinis Iovi Elicio aram in

${ }^{13}$ Fig. 21. RIC $\mathrm{I}^{2} 367$.

${ }^{14} R I C \mathrm{I}^{2} 410$.

${ }^{15}$ Fig. 22. RIC $\mathrm{I}^{2} 422$.

${ }^{16}$ For further reference on this coin type, see GYÖRI, V.: From Republic to Principate: Change and Continuity in Roman Coinage. PhD thesis. King's College London 2012, 165-166.

${ }^{17}$ Fig. 23. RIC $\mathrm{I}^{2} 207$.

${ }^{18}$ Fig. 24. RPC I 771, 826, and 322.

${ }^{19}$ Fig. 25. RPC I 319.

${ }^{20}$ E.g. $R P C$ I 178.

${ }^{21}$ Fig. 26. RRC 242/1.

${ }^{22}$ Fig. 27. RRC 334/1. 
Aventino dicavit deumque consuluit auguries, quae suscipienda essent [On account of eliciting this knowledge from the minds of the gods, Numa dedicated an altar on the Aventine to Jupiter Elicius, and consulted the god by augury so that (he may know which) portents should be regarded].

From the time of Sulla onwards, however, there was a tendency to symbolize the extension of the augur's duty to the military sphere and the lituus began to be combined with military iconography. Scholars have thus associated the lituus with military auspices and superior imperium. Alföldi writes that "the capis and the lituus stand for the two aspects of imperatorial power: ductu auspicioque" (ductu auspicioque - a common phrase in Roman historiography meaning "by conduct and the auspices"). Fears says "the lituus on late Republican coinage presents in microcosm the history of the theology of the victory at Rome." In regards to Sulla's reverse type of 84-83 BC (Fig. 28), ${ }^{23}$ which shows a jug and lituus in between two trophies with the legend IMPER ITERVM, Crawford says "the jug and the lituus symbolized a claim to imperium". 24

The lituus then appears on obverse portraits, for instance, of Julius Caesar in 44 BC, Pompey the Great in 42-40 BC (posthumous issue minted by Sextus Pompey), and Antony in $40 \mathrm{BC}^{25}$ The portrayal of Octavian on Antonian coins and vice versa, which on the face of it advertises unity, in fact reveals rivalry in the omission of priestly symbols and religious titles. For instance, an Antonian obverse type portrays Antony with the legend M ANTONIVS III VIR R P C and a lituus while the reverse shows Octavian with the legend C CAES III VIR R P C without any priestly emblem. On another coin, the Antonian obverse is the same as the preceding while the reverse depicts Lepidus with the legend M LEPIDVS III VIR R P C and an aspergillum and a simpulum. ${ }^{26}$ Full-length figures of Q. Cornificius and Antony dressed as augurs (togate and wearing a veil) holding a lituus were also seen on coins dated to $42 \mathrm{BC}$ and $38 \mathrm{BC}$, respectively. Cornificius is also shown being crowned with a laurel wreath by Juno Sospita. ${ }^{27}$ Other priestly emblems certainly appear, such as on an obverse portrait of Caesar in 44 BC depicting a lituus as well as a simpulum (Fig. 34) ${ }^{28}$ and the portrait of Antony depicting a capis in $41 \mathrm{BC}$, as seen on Fig. 3. More than two priestly emblems appear together rather frequently, as seen on a Caesarian coin of $46 \mathrm{BC}$ showing the simpulum, apex, jug, and lituus with the legend AVGVR PONT MAX

${ }^{23}$ Fig. 28. RRC 359.

${ }^{24}$ ALFÖLDI, A.: The main aspects of political propaganda on the coinage of the Roman Republic. In Carson, R. A. G - Sutherland, C. H. V. (eds.): Essays in Roman Coinage Presented to Harold Mattingly. Oxford 1956, 63-95, here 86; FEARS, J. R.: Theology of victory at Rome. ANRW II.17.2. (1981) 736-826, here 804; and RRC 374. This Sullan reverse type is heavily debated in scholarship. For a recent summary, see Koortbojian, M.: The Divinization of Caesar and Augustus: Precedents, Consequences, and Implications. Cambridge 2013, 64-73.

${ }^{25}$ Figs 29-31, respectively. RRC 480/2a, 511/3a, and 520.

${ }^{26}$ RRC 492/1-2. See also NEWMAN, R.: A dialogue of power in the coinage of Antony and Octavian 44-30 BC. AJN 2 (1990) 37-63.

${ }^{27}$ Figs 32-33, respectively. RRC 509/2 and 533/2. For this coin type of Q. Cornificius, see FEARS, J. R.: The coinage of Q. Cornificius and augural symbolism on Late Republican denarii. Historia 24 (1975) 592-602.

${ }^{28}$ Fig. 34. RRC 480/3. 
(Fig. 35). ${ }^{29}$ However, the lituus appears about thirty times while the apex, aspergillum, and simpulum appear about only ten times each. ${ }^{30}$

\section{THE LITUUS ON AUGUSTAN WORKS OF ART}

The lituus appears on some well-known Augustan art works of various media. Here also, as on the Late Republican coins that have been discussed in the previous sections, it may refer to Augustus' successful military auspices. On the Vicus Sandaliarius altar (Fig. 36), ${ }^{31}$ dated to $2 \mathrm{BC}$, a scene of augury is depicted in relation to Gaius' departure to the East in 2 BC. Augustus is seen veiled and togate, holding a lituus in his right hand, standing in between Gaius Caesar and Livia, with a chicken pecking below. That the chicken is pecking refers specifically to the tripudium, a type of military auspices that involves the eating habits of chickens. That Augustus, and not Gaius, is holding the lituus shows that Gaius' Eastern campaign was to be undertaken with Augustus' auspices since he held superior imperium. A sardonyx in Florence depicts Gaius on horseback in front of Augustus who is enthroned, crowned by Victory and holding a lituus (Fig. 37). ${ }^{32}$ This scene also refers to Gaius' departure to the East in 2 BC. It should be noted that the image of Gaius on horseback with military standards corresponds exactly to a reverse type minted in 8-6 BC in Lugdunum depicting Gaius on horseback with three military standards behind him (Fig. 38). ${ }^{33}$ This coin type, however, refers to Gaius' participation in military exercises with the Rhine legions in $8 \mathrm{BC}$ since he still wears a bulla. The bulla was customarily worn until a boy assumes the toga virilis, which Gaius took in 5 BC. ${ }^{34}$ The Gemma Augustea (Fig. 39), ${ }^{35}$ dated to c. AD 10, shows Augustus enthroned in a guise like Jupiter holding a sceptre in his left hand and a lituus in his right hand. He is seated next to Roma and crowned by Oikomene while Tiberius descends from a chariot driven by Victoria with Germanicus to the left. The lower zone shows Roman soldiers erecting a trophy amongst defeated barbarians. This whole scene celebrates Tiberius' command in Pannonia under Augustus' auspices. However, the depiction of the lituus evokes first and foremost the augur's role as the interpreter of Jupiter's will on earth and mediator between gods and men. ${ }^{36}$ The Grand Camée de France, dated to c. AD 23, presents a similar theme (Fig. 40). ${ }^{37}$ Here, Tiberius is Jupiter-like, enthroned, holding a sceptre in his left hand and a lituus in his right. He is surrounded by members of the imperial fam-

${ }^{29}$ Fig. 35. RRC 467/1a.

${ }^{30}$ For a concise summary on priestly emblems on Republican coins, see MORAWIECKI, L.: Pontificalia atque auguralia insignia and the political propaganda in the coinage of the Roman Republic. Notae Numismaticae 1 (1996) 37-57.

${ }^{31}$ Fig. 36. Uffizi, Florence.

${ }^{32}$ Fig. 37. Museo Archeologico, Florence.

${ }^{33}$ Fig. 38. RIC $\mathrm{I}^{2} 199$.

${ }^{34}$ For further reference on this coin type, see GYÖRI: From Republic (n. 16) 164-165.

${ }^{35}$ Fig. 39. Kunsthistorisches Museum, Vienna.

${ }^{36}$ See also Galinsky, K.: Augustan Culture. Princeton 1996, 120-121.

${ }^{37}$ Fig. 40. Bibliothèque Nationale, Paris. 
ily, including Livia seated next to him and the deified Augustus with a sceptre reclining above. Germanicus is shown in front of Tiberius receiving auspices for his Eastern campaign. ${ }^{38}$ Two other works also show Augustus holding a lituus alongside military symbols. A fragment of an Arretine ware of Augustan date (Fig. 42) ${ }^{39}$ depicts Augustus holding a lituus in his right hand and a globe in his left. A laurel branch is seen behind Augustus' head. A medallion which decorated a scabbard from Switzerland, dated to after AD 9, depicts a laureate head of Augustus wearing a cuirass and a $p a-$ ludamentum (military cloak) and being crowned by Victory carrying a cornucopia. In front of Augustus is a lituus (Fig. 43). ${ }^{40}$

\section{AUGUSTUS’ ROLE AS A FOUNDER}

While it is true that the lituus may symbolize a senior magistrate's duty of taking the military auspices, with advice from augurs, as is illustrated on some Late Republican coins and works of art which evoke Augustus' auspices and supreme military command, I would argue that the lituus in Augustan imagery primarily reflects Augustus' role as a founder. Its frequency on coins minted at Rome fits better with this general civic claim than with the narrower claims to victory for which there were more direct iconographic allusions. The frequency of the lituus on obverse portraits of Augustus on provincial coinage is also best interpreted as honouring Augustus for the founding, re-founding, or reorganizing of Rome as well as many provincial cities.

Roman tradition asserted that Romulus had founded the city of Rome by augury. In order to decide who would name the new city and rule over it after its foundation, Romulus and Remus resorted to augury. Remus went to the Aventine and Romulus the Palatine to take the auspices. Six vultures appeared to Remus while twelve to Romulus. In their subsequent quarrel, Romulus killed Remus and then gave his name to the city and became Rome's first king. Ennius says that glorious Rome was founded by 'august augury' (augusto augurio postquam inclita condita Roma est) and Cicero refers to Romulus as optimus augur. ${ }^{41}$

From the start of Octavian's rise to power, Octavian associated himself with Romulus' role as augur. Suetonius writes that when Octavian was taking auspices in $43 \mathrm{BC}$, the year of his first consulship, "twelve vultures appeared to him, as to Romulus". ${ }^{42}$ Octavian became augur in late 43 BC. It was not a coincidence that Octavian lived on the Palatine, where Romulus had once lived, and in particular he took up residence in the house of the Hortensii, which was located very near to Roma Quadrata, where Romulus was said to have taken his auspices. Suetonius, Augustus 31. 4,

${ }^{38}$ See also Fig. 41, a sardonyx from the Bibliothèque Nationale in Paris dated to after AD 54 which depicts the apotheosis of Claudius. Claudius is enthroned, crowned by Victory and holding a lituus in his right hand.

${ }^{39}$ Fig. 42. GAGÉ, J.: Romulus-Augustus. MEFR 47 (1930)138-181, here 168.

${ }^{40}$ Fig. 43. Vindonissa Museum, Switzerland.

${ }^{41}$ Ennius, Ann. $245 \mathrm{M}$ and Cicero, de divin. I 2.

${ }^{42}$ Suetonius, Aug. 95. 
and Dio 51. 20. 4 tell us that in 29 BC Octavian performed one of the most important auguries, the augurium salutis. Through this, he was celebrated as bringer of peace to Rome, and this ceremony was repeated several times before his death.

The name 'Augustus' has a clear connection with the words augur, augere, and augurium. Ovid, Fasti 1. 607-616, points out the augural significance of his name: "the fathers call holy things august ... and from this very word augury derives, as well as whatever Jupiter augments ... let Jupiter augment our leader Augustus' imperium and augment his years". Suetonius, Augustus 7. 2, says that Octavian was given the new title of Augustus since sacred places or anything consecrated by augural rites are called 'august' from the increase in dignity. Dio 53. 16. 6-8 also says that all prized and sacred things are called 'august' and that for this reason Augustus is called Sebastos in Greek, meaning someone revered, from sebazesthai, to revere. ${ }^{43}$

Augustus particularly associated himself with Romulus' role as the first founder of Rome. Brunt says that "it was Romulus as conditor rather than as rex who presented a model for imitation". "In Cat. 3. 2, Cicero implies that Romulus was awarded deification on account of his founding Rome: quoniam illum qui hanc urbem condidit ad deos immortales benevolentia famaque sustulimus ... "since we have elevated to the immortal gods that man (Romulus) who founded this city (Rome) through his goodness and glory...". In Balb. 13. 31, he also calls Romulus the first creator of the city - princeps ille creator huius urbis Romulus. Concerning the auspices of Romulus and the sacra of Numa, Cicero writes in De Natura Deorum 3. 2. 5 that "Romulus, by founding the ritual of taking the auspices, and Numa, by founding the sacra, laid the foundations of our state (Romulum auspiciis Numam sacris constitutis fundamenta iecisse nostrae civitatis). In Aeneid 6. 781-783, Anchises prophesizes to Aeneas that under Romulus' auspices, Rome will enclose her seven walls within a single wall. In Praef. 7, Livy calls Romulus a conditor. In 1. 7. 3, Livy says that the city (Rome), thus founded, was called by its founder's (Romulus') name. In 5. 53. 8, Livy refers to the well-known hut on the Palatine as the hut of our founder. The first temple, to be consecrated in Rome, the temple of Jupiter Feretrius, was established by Romulus. Livy names Romulus as the conditor of this temple in 1. 10. 7. Augustus was himself hailed as a second founder of Rome and as a universal founder in the provinces. Syme says "Augustus had a real claim to be known and honoured as the Founder, 'augusto augurio', in the phrase of Ennius." 45 Suetonius, Augustus 7. 2, says that some wished Octavian to be called Romulus, as a second founder of Rome. Florus emphasizes the role of Augustus as a second founder of Rome: "it was discussed in the Senate whether

${ }^{43}$ Scholarship on the significance of the name 'Augustus' is extensive. See, for example, TAYLOR, L. R.: Livy and the name Augustus. CR 32 (1918) 158-161; SCOTT, K.: The identification of Augustus with Romulus-Quirinus. TAPA 56 (1925) 82-105; HIRST, G.: The significance of Augustior as applied to Hercules and Romulus: a note on Livy 1.7.9 and 1.8.9. AJP 47 (1926) 347-357; GAGÉ (n. 39) 162-167, ZECCHINI, G.: Il cognomen «Augustus». ActaClDebrec 32 (1996) 129-135 and ToDISCO, E.: Il nome AUGUSTUS e la 'fondazione' ideological del principato. In DESIDERI, P. - MOGGI, M. - PANI, M. (eds.): ANTIDORON. Studi in onore di Barbara Scardigli. Pisa 2007, 441-462.

${ }^{44}$ FeARS, J. R.: Princeps a Diis electus: The Divine Election of the Emperor as a Political Concept at Rome. Rome 1977. Review by P. A. BRUNT in JRS 69 (1979) 168-175, here 171.

${ }^{45}$ SyME, R.: The Roman Revolution. Oxford 1939, 520. 
Octavian be called Romulus, since he founded the empire, but the name Augustus was deemed more sacred and reverent" (Florus 3. 34. 66). Dio 53. 16. 4-8 shows that the events of 28-27 BC, through which Octavian handed over the state to the judgment of the Senate and the people of Rome (Res Gestae 34. 1), was the reason that the name Romulus was suggested for Octavian. The transferring of the res publica to the Senate and people of Rome (by such means as the restoration of statutes and laws to the people of Rome as recorded on Octavianic aureii of $28 \mathrm{BC}$ from Ephesus bearing the reverse legend LEGES ET IVRA P R RESTITVIT ${ }^{46}$ ) was considered to be a return to constitutional normality in many ancient narratives. ${ }^{47}$ In 4. 20. 7, Livy calls Augustus the "restorer and founder of all our temples" (templorum omnium conditorem ac restitutorem). Here, Livy clearly recalls naming Romulus as the conditor of the temple of Jupiter Feretrius in 1. 10. 5-7. Whereas the rebuilding of the 82 temples is mentioned in Res Gestae 20. 4, the restoration of the temple of Jupiter Feretrius is presented as one of his own foundations in Res Gestae 19. In these passages of Livy and the Res Gestae, Augustus is seen as the saviour of those temples that were neglected during the period of the civil wars. In Aeneid 6. 792, Anchises predicts to Aeneas that Augustus will found a Golden Age (aurea condet saecula), a period of prosperity and bliss. ${ }^{48}$ Indeed, in Ode 3. 24. 27, Horace calls him the pater urbium. Augustus mentions the colonies he founded three separate times in the Res Gestae: 3. 3, 16. 1-2, and 28. $1 .^{49}$ He also re-founded and reorganized many existing Roman colonies. He was given the title ktistes in many cities in the East.

The types of founding attributed to Romulus and Augustus correspond to the Hellenistic and Late Republican concepts of foundation. Foundation may refer to the establishment of a new community; the title of ktistes or conditor means the original founder of a community. Foundation may also refer to providing an existing community with a new constitution. In this case, the existing community would be renamed and the one under whose authority the community was reconstituted became its new founder. The title of ktistes or conditor was also granted as an honorific title in gratitude for the one who saved a city from destruction (e.g. physical - rebuilding a city after an earthquake, political - liberation from a tyrant), that is, a saviour or a benefactor can be called the new ktistes (or re-founder) of a city. These roles are related to other titles such as soter and euergetes or even pater, parens, custos, conservator, or restitutor and are found together in many variations - with soter kai ktistes as one of the most common epithets. ${ }^{50}$ The equivalence between these terms gave room for numer-

\footnotetext{
${ }^{46} \mathrm{BM}$ accession no. CM 1995, 4-1.1.

${ }^{47}$ E.g. Cassius Dio 53, Tacitus, Ann. 3. 28, and Res Gestae 34. For more on this coin type, see below pp. 56-57.

${ }^{48}$ On an Augustan aurea aetas, see GYÖRI, V.: The Aurea Aetas and Octavianic/Augustan coinage. OMNI 8-10 (2014) 36-56.

${ }^{49}$ Cf. Suetonius, Aug. 46-47.

${ }^{50}$ The title of pater patriae that was awarded to Augustus is clearly one of his most significant titles. See also the obverse legend on coins minted in Spain at Colonia Patricia dated to c. 18-16 BC which reads: SPQR PARENTI CONS(ervatori) SVO ("the Senate and the people of Rome (awarded the ornamenta triumphalia) to their parent and conservator") - RIC I ${ }^{2} 96-101$.
} 
ous Hellenistic monarchs and Roman figures (legendary and historical) to be deemed founders or re-founders. ${ }^{51}$

Many Hellenistic monarchs were founders or re-founders of cities. For instance, after the capture of Amphipolis in 357 BC, Philip II of Macedon re-founded the city of Crenides as Philippoi and Eumolpias as Philippopolis in Thrace. In On the Fortune or Virtue of Alexander I 328e, Plutarch writes that "Alexander established more than 70 poleis among barbarian peoples, and planted Asia with Greek magistrates, and thus overcame its brutish and uncivilized way of life". While this exact number may not be accurate, Alexander the Great indeed founded and re-founded numerous cities in the East. Alexander's most significant new city foundation was of course Alexandria in Egypt which was founded in 331 BC. A Ptolemaic cult of Alexander Ktistes was instituted there, and Alexander was honoured with a bronze equestrian statue that served as its cult statue. ${ }^{52}$ After 307 BC, when Antigonus sent his son Demetrius Poliorcetes to liberate Athens, Demetrius was given the titles of Soter and Euergetes. Demetrius and Antigonus were given the name of saviour-gods. ${ }^{53}$ Kaerst implies a connection between a ktistes and a soter by saying "the Athenians received from the liberating and saving hands of the two rulers a new foundation of the state". ${ }^{54}$ In 303 $\mathrm{BC}$, Demetrius persuaded the people of Sicyon to move to a more advantageous site. As a result, the citizens "changed the name of their city to Demetrias, and they voted to grant him sacrifices, festivals, and, further, annual games and to render him other honours as to a founder". 55

Legendary heroes and kings of Rome other than Romulus as well as some historical Republican figures were also honoured as founders. Aeneas was the founder of Lavinium, the Trojans' first permanent settlement in Italy. He established this city at the spot where the sow gave birth to thirty piglets. ${ }^{56}$ In Aeneid 8. 313, Vergil calls Evander the founder of the Roman citadel (Euandrus Romanae conditor arcem). ${ }^{57}$ In Aeneid 8. 357, he also attributes to Janus and Saturn, who both organized the Latins into communities governed by laws, the founding of the Roman citadel (hanc Ianus

${ }^{51}$ For these definitions of foundation, see MILES, G. B.: Livy. Reconstructing Early Rome. Ithaca, NY 1995, 103-105 and 120-121. On the link between the titles ktistes, conditor, soter, euergetes, and so on, see HABICHT, C.: Gottmenschentum und griechische Städte [Zetemata. Monographien zur klassischenaltumswissenschaft 14]. Munich 1956, 204-205; CLASSEN, C. J.: Romulus in der römischen Republik. Philologus 106 (1962) 174-204, here 181-183; CLASSEN , C. J.: Gottmenschentum in der römischen Republik. Gymnasium 70 (1963) 312-338, here 335-336; and WeINSTOCK, S.: Divus Julius. Oxford 1971, 177, 181-183, 202; and NocK, A. D.: Soter and Euergetes. In STEWART, Z. (ed.): Essays on Religion and the Ancient World. Oxford 1972, 720-735. T 126, S 18 .

52 STEWART, A.: Faces of Power: Alexander's Image and Hellenistic Politics. Berkeley 1993,

${ }^{53}$ Plutarch, Dem. 9. 1 and 10. 3.

${ }^{54}$ KAERST, J.: Geschichte des Hellenismus. Berlin 1927, 314.

${ }^{55}$ Diodorus 20. 102. 3. For further reference on Demetrius Poliorcetes as ktistes and soter, see, for instance, SCOTT, K.: The Deification of Demetrius Poliorcetes. Part II. AJP 49 (1928) 217-239.

${ }^{56}$ Vergil, Aen. 3. 389-393 and 8. 81-85; Dionysus of Halicarnassus 1. 56-57. Aeneas is also the principal founder of Rome in Tibullus 2. 5.

${ }^{57}$ For further reference on Evander as one of the founders of Rome, see PAPAIOANNOU, S.: Founder, civilizer, and leader. Vergil's Evander and his role in the origins of Rome. Mnemosyne 56 (2003) 680702. 
pater, hanc Saturnus condidet arcem). ${ }^{58}$ Numa, the second king of Rome, was by tradition known as the priest king while Romulus was known as the warrior king. Although Numa is not explicitly named conditor in 1. 19. 1, Livy writes: urbem nouam conditam ui et armis, iure eam legibusque ac moribus de integro condere parat "the city (Rome), recently founded by force and arms (by Romulus), he (Numa) prepares to found anew on a legal basis with laws and customs". Vergil also says Numa was the Roman king who built Rome on laws. ${ }^{59}$ Camillus was deemed a conditor alter by Livy in 5. 49. 7-8 because of his expulsion of the Gauls from Rome and preventing his fellow citizens from abandoning Rome for Veii. Camillus' salvation of Rome is equated to a re-foundation of the city. Marius is called a third founder (triton ktisten) by Plutarch since he saved Rome from destruction by the Cimbri. ${ }^{60}$

Cicero writes that "there is no other act in which human virtus approaches more closely the divinity of the gods than that of founding new cities or founding or of preserving those already founded". ${ }^{61}$ In Cat. 3. 2, as mentioned above, he goes on to say "...he who has preserved this same city after it had been founded and enlarged it will deserve to be held in honour by you and your prosperity". ${ }^{62}$ He does not expressly name himself a conditor, but certainly compares himself to Romulus for saving Rome from the Catilinarian conspiracy. Although Cicero did not officially receive such titles, Plutarch does in fact refer to him as soter kai ktistes. ${ }^{63}$ In inscriptions from Mytilene, Pompey the Great was called ktistes, soter kai ktistes and euergetes kai soter kai ktistes. Mytilene also named a month after him. ${ }^{64}$ A city in Cilicia restored by Pompey took the name Pompeiopolis and issued bronze coins with his obverse portrait after $66 \mathrm{BC}$ (Fig. $44^{65}$ ). Pompeiopolis also began to count a new era from the day Pompey liberated it ${ }^{66}$. Julius Caesar also founded and re-founded numerous cities both in the West and in the East. For instance, in Gaul, Caesar founded Colonia Iulia Paterna Arelate, Colonia Colonia Iulia Viennensis, and Forum Iulii. In Africa, he founded Colonia Iulia Concordia Karthago and Colonia Iulia Pia Paterna. In the East on the Hellespont, he founded the twin colonies of Parium and Lampsacus. At Lampsacus,

\footnotetext{
${ }^{58}$ For further reference on Saturn as one of the founders of Rome, see JOHNSTON, P. A.: Vergil's Conception of Saturnus. CSCA 10 (1977) 57-70.

${ }^{59}$ Vergilius, Aen. 6. 810-811. For further reference on the association between Augustus and Numa, see GYÖRI, V.: Augustus and Numa: the asses of 23 BC. In RosATI, G. - LABATE, M. (eds.): La costruzione del mito augusteo. Heidelberg 2013, 89-108.

${ }^{60}$ Plutarch, Marius 27. 9. On Camillus and Marius as conditores of Rome, see WEINSTOCK (n. 51) 177-184 and MiLES (n. 51) 88-95 and 104-105.

${ }^{61}$ Cicero, De rep. 1. 12: neque enim est ulla res in qua propius ad deorum numen virtus accedat humana, quam civitatis aut condere novas aut conservare iam conditas.

${ }^{62}$ Cicero, Cat. 3. 2: ... esse apud vos posterosque vestros in honore debebit is qui eandem hanc urbem conditam amplificatamque servavit.

${ }^{63}$ Plutarch, Cicero 22. On Cicero, see WeINSTOCK (n. 51) 179-180.

${ }^{64} I G$ 12. 2. $163,12.2 .202,12.2$. 141 , and 12. 2. 165.

${ }^{65}$ Fig. 44. SNG Paris 1215.

${ }^{66}$ On these coins, Taylor writes "here is a Roman with all the glory of a Greek city founder" (TAYLOR, L. R.: The Divinity of the Roman Emperor. Middletown, Conn. 1931, 40). See also BoYCE, A. A.: The foundation year of Pompeiopolis in Cilicia. A statement of a problem. In BIBAUW, J. (ed.): Hommages à Marcel Renard. Bruxelles 1962, 87-103.
} 
coins were minted around $45 \mathrm{BC}$ with a reverse type depicting a priest ploughing with oxen. This is clearly a standard numismatic motif for representing the foundation of a city (Fig. 45) ${ }^{67}$ After Caesar's victory at Pharsalus, he received numerous honours in the East, including the titles of euergetes, soter, and ktistes. On a public dedication at Mytilene, he is theos, euergetes, soter, and ktistes. ${ }^{68}$ After the victory at Philippi, similar honours were given to Antony. ${ }^{69}$ Indeed, a colony was founded at Philippi in $42 \mathrm{BC}$ by Antony, and its foundation was celebrated by coins imitating Caesar's "ploughing" type from Lampsacus. ${ }^{70}$

Augustus promoted his image as a founder in this tradition of a long line of Roman conditores. As discussed above, the role of being a ktistes was also extremely important for Hellenistic monarchs. He received such titles as eleutherios, theos, euergetes, soter, and ktistes. Among his many foundations and re-foundations are Nicopolis, Tralles (Caesarea), Pisidian Antioch (Colonia Caesarea), Alexandria Troas, Patras, Emerita, and Colonia Caesaraugusta. Among the many cities he specifically granted freedom to were Chios, Samos, Cnidus, Amisus, and Tarsus. ${ }^{71}$

In Res Gestae 1. 1, Augustus says he vindicated the liberty of the republic, oppressed by tyranny of a faction. The LIBERTATIS P R VINDEX cistophori minted in $28 \mathrm{BC}$ in Ephesus refer to Octavian's victory at Philippi and Actium as well as to the political events of 28-27 BC. Indeed, libertas was one of the principal slogans on the coinage of Brutus and Cassius in $42 \mathrm{BC}$. The imagery on these Octavianic cistophori is directly influenced by Antonian cistophori. On the obverses, Antony wears an ivy wreath while Octavian wears a laurel one. On the reverses, the figure of Dionysus holding a thyrsus is replaced by Apollo holding a caduceus. The cista mytica is moved to the side, the snakes are eliminated, and while an ivy wreath encompasses the whole of the obverse of one of these Antonian cistophori, a laurel wreath encompasses the whole of the reverses of the Octavianic coins (Fig. 46 and 47, respectively). ${ }^{72}$ However, these Octavianic cistophori were issued together with the LEGES ET IVRA P R RESTITVIT mentioned above (Fig. 48) ${ }^{73}$ As recorded by Tacitus, Annales 3. 28. 1-2, and Dio 53. 2. 5, in 28 BC Octavian annulled his triumviral acts. Other measures were also taken by Octavian in the same year, such as those relating

${ }^{67}$ Fig. 45. RPC I 2268-9.

${ }^{68} I G$ 12. 2. 165. Cf. TAYLOR: The Divinity (n. 65) 267-269.

${ }^{69}$ TAYLOR: The Divinity (n. 65) 269 and FISHWICK, D.: The Imperial Cult in the Latin West. Studies in the Ruler Cult in the Western Provinces. 2 vols. Leiden 1987, I 48.

${ }^{70}$ RPC I 1646.

${ }^{71}$ For a general survey of cities founded, re-founded, or granted free status by Augustus, see, for instance, Pliny, NH 3-6; BROUGHTON, T. R. S.: Some non-colonial coloni of Augustus. TAPA 66 (1935) 18-24; Grant, M.: From Imperium to Auctoritas. A Historical Study of Aes Coinage in the Roman Empire 49 BC-AD 14. Cambridge 1946; MAGIE, D.: Roman Rule in Asia Minor to the End of the Third Century after Christ. Princeton 1950, 468-490; KEPPIE, L.: Colonisation and Veteran Settlement in Italy 47-14 BC. London 1983; NICOLET, C.: L'inventaire du monde : géographie et politique aux origines de l'Empire romain. Paris 1988; RPC I; RAMAGE, E.: Augustus' propaganda in Gaul. Klio 79 (1997) 117160; Ramage, E.: Augustus' propaganda in Spain. Klio 81 (1999) 434-490; and MACMulleN, R.: Romanization in the Time of Augustus. Yale 2000.

${ }^{72}$ Fig. 46 and 47. RIC I 476 and RPC I 2202.

${ }^{73}$ Fig. 48. BM accession no. CM 1995, 4-1.1. 
to the renewal of free elections and to the treasury. Rich and Williams attractively suggest that these coin legends derive from a Senatorial decree of $28 \mathrm{BC}$ referring to Octavian's role as a liberator and restorer. ${ }^{74}$ It should of course be noted that the Octavianic IMP CAESAR reverse type of c. 32-27 BC depicting Octavian ploughing with yoke of oxen was issued contemporaneously with the Octavianic quinarii depicting an obverse portrait of Octavian with a lituus and the crocodile with the AEGVPTO CAPTA legend on the reverse. It was also c. 27-26 BC when Pergamum issued some cistophori with obverse portraits of Augustus with a lituus. The majority of scholars refer this IMP CAESAR coin of c. $32-27 \mathrm{BC}$ to the founding of Nicopolis. ${ }^{75}$ It is true that a "ploughing" type usually refers to the foundation of a colony, but, in this case, as well as in the case of the coin of $13 \mathrm{BC}$ minted by the Roman moneyer C. Marius Tro, it is a general allusion to Octavian's role as a founder. On this reverse type, Sutherland writes that "Octavian is the founder and re-founder of urban communities". ${ }^{76}$ The CAESAR DIVI F and IMP CAESAR series of c. 32-27 BC can be characterized in a "Hellenistic monarchic" tradition, that is, Octavian styled himself in a myriad of Hellenistic monarchic roles: e.g. military commander, world conqueror, triumphator. Another one of these important roles was clearly that of a founder. ${ }^{77}$ Augustus was also honoured as Zeus Eleutherios in Mytilene, and it seems to have been his official title in Egypt. He was honoured as Apollo Eleutherios in Caria. ${ }^{78}$

In numerous cities, Augustus was named euergetes, soter, and ktistes. For instance, at Athens, Augustus is called ktistes. The citizens of Cos honoured him as the founder of the city. At the Heraion of Samos, a dedication was made to Augustus as "Olympian, euergetes, soter, and ktistes". At Amisus, he is soter and ktistes. At Tlos, he is theos, soter, and ktistes. On an inscription from Pergamum, he is theos, euergetes, and ktistes. ${ }^{79}$

It is not surprising then, that Augustus was prominently depicted as a founder on provincial coinage. Nicopolis was founded by Octavian in commemoration of his Actian victory. Coins issued at Nicopolis during Augustus' reign bear the legend

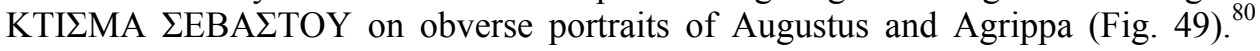
In Spain, Augustus founded Emerita in about $25 \mathrm{BC}$ and Colonia Caesaraugusta in about $19 \mathrm{BC}$ with veterans from the Cantabrian Wars. Both of these cities issued coins with "ploughing" reverse types, and in Colonia Caesaraugusta an obverse portrait of

${ }^{74}$ For these Octavianic coin types, see MANNSPERGER, D.: Apollon gegen Dionysus. Numismatische Beiträge zu Octavians Rolle als Vindex Libertatis. Gymnasium 80 (1973) 381-404; and RICH, J. W. Williams, J. H. C.: Leges et Ivra P. R. Restitvit. A new aureus of Octavian and the settlement of 28-27 BC. NC 159 (1999) 169-213. For libertas on Brutus and Cassius' coins, see RRC 501/1 and 498/1 and HoLLSTEIN, W.: Apollo und Libertas in der Münzprägung des Brutus and Cassius. JNG 44 (1994) 113-133.

${ }^{75}$ E.g. KRAFT, K.: Zur Münzprägnung des Augustus. Wiesbaden 1969, 211-215.

${ }^{76}$ SUTHERLand, C. H. V.: Coinage and Roman Imperial Policy 31 BC-AD 68. London 1951, 30.

77 On the "Hellenistic monarchic" tradition of the Octavianic CAESAR DIVI F and IMP CAESAR series, see GYÖRI: From Republic (n. 16) 37-75.

${ }^{78} I G$ 12. 2. 156 (Zeus Eleutherios in Mytilene) and TAYLOR: The Divinity (n. 65) 270 (Zeus Eleutherios in Egypt); OGIS 457 (Apollo Eleutherios in Caria).

${ }^{79}$ CIA 3. 430, Dittenberger, Inschriften von Olympia 53, IG 12. 6. 1. 400, IGR 4. 314, 3. 426, and 4. 311, respectively. For a fuller list, see TAYLOR: The Divinity (n. 65) 270-283.

${ }^{80}$ Fig. 49. RPC I 1363-1367. 
Augustus depicts him with a simpulum and a lituus (Fig. 50). ${ }^{81}$ As colonies founded by Augustus, Antioch and Patras also issued coins with the "ploughing" reverse type (Fig. 51). ${ }^{82}$

Some cities that were founded by or owed their status to Caesar or Antony were later re-founded by Augustus. Colonia Iulia Pia Paterna was a Julian colony re-founded by Augustus. The epithet Iulia attributes this colony's foundation to Caesar while the epithets Pia Paterna are attributed to a re-founding by Augustus. Another coin type minted contemporaneously with the obverse type depicting Augustus with a lituus, shows a diademed head of Caesar on the obverse and Ceres walking, holding a torch in each hand with a plough in front on the reverse (Fig. 52) ${ }^{83}$ Ceres represents the prosperity bestowed by its foundation. Hadrumetum, Thaena, Leptis Minor were free cities under Caesar, and it is possible that Caesar planned for their foundations as colonia. Indeed, posthumous obverse portraits of Caesar minted under Augustus depict Caesar with a lituus and/or a star. ${ }^{84}$ Hadrumetum became a municipium under Augustus. Thaena and Leptis Minor both owed their privileged status to Caesar that was later extended to Augustus' reign. Numerous cities in the East were reorganized during Augustus' reign, that is, they underwent new reforms instituted by Augustus. They commemorated the constitutor Augustus by minting portrait issues of him represented more often than not with a lituus. For instance, at Eumenea, Augustus is depicted with a lituus, referring to the changes Augustus made for the city that was previously renamed Fulvia by Antony during his visit to the East in $41 \mathrm{BC}$. Augustus also most likely reformed the Antonian constitutions of Acmonea, Amorium, Apamea, Apollonia Salbace, Dioshieron, Eucarpia, Siblia, and Prymnessus. ${ }^{85}$

Other cities that regained their liberty under Augustus also depicted Augustan portraits with a lituus. The cities of Oea and Sabratha in the province of Africa recovered their liberty under Augustus after 12 BC. After the Battle of Thapsus, Caesar did not confirm the liberty of these cities. However, a grant of libertas by Augustus was granted to Oea and Sabratha as well as Leptis Magna soon after 12 BC. ${ }^{86}$

The legend, $\Sigma$ EBA $\Sigma T O \Sigma$ KTI $\Sigma T H \Sigma$, appears on obverse portraits of Augustus at Clazomenae and at Teos (Fig. 53). ${ }^{87}$ Augustus re-founded these cities after they were damaged by the earthquake (of either $47 / 46,26$, or $12 \mathrm{BC}$ ). After the earthquake of $26 \mathrm{BC}$, Tralles appealed to Augustus for aid. Augustus re-founded it as Caesarea and settled Italians there to rebuild the city. ${ }^{88} \mathrm{He}$ was thus called the "founder of the city" ${ }^{89}$ At the same time as the obverse portrait of Augustus with a lituus was minted

${ }^{81}$ Fig. 50. $R P C$ I 5 and 306.

${ }^{82}$ Fig 51. $R P C$ I 3529 and 1252.

${ }^{83}$ Fig. 52. RPC I 759 and 761.

${ }^{84} R P C$ I $772 \mathrm{a}$ and $772 \mathrm{~b}$.

${ }^{85}$ GRANT: From Imperium (n. 71) 346-355. See also GRANT, M.: Phrygian Metropolis in the early Principate. NC 9 (1949) 157-165. for Metropolis which has now been reattributed from Phrygia to Ionia in RPC I 2524-2525.

${ }^{86}$ GRANT: From Imperium (n. 71) 339-341.

${ }^{87}$ Fig. 53. RPC I 2494-2495 and 2511-2512.

${ }^{88}$ Strabo, 12. 8. 18 (579) and Agathias 2. 17.

${ }^{89}$ MAGIE (n. 71) 1331, n. 7. 
in Tralles around $2 \mathrm{BC}$, a coin type was issued with the head of Gaius on the obverse and a "ploughing" scene on the reverse (Fig. 54). ${ }^{90}$ Laodicea also was reconstructed after an earthquake destroyed it in $20 \mathrm{BC}$.

\section{CONCLUSIONS}

Augustus' position as an augur is therefore preeminent in his visual imagery. The farreaching evidence of the lituus on Augustan provincial coinage, in particular, suggests that the reason for this goes back to Romulus' foundation of Rome by augury, and the role of a universal founder was adopted by Augustus as one of his most significant roles. This is particularly evident on the coinage of his time. He wished to establish that he was a second founder of Rome as well as a founder and re-founder of numerous cities in the Roman provinces.

Victoria Győri

Dept. of Classics

King's College London

B3, North Wing, Strand

London WC2R 2LS

${ }^{90}$ Fig. 54. RPC I 2649. 